\title{
Efektivitas Biji Kelor (Moringa Oleifera Lamk) Pada Pengolahan Air Sumur dan Penentuan Waktu Optimum Adsorpsi Biji Kelor Terhadap Fe dan Mg Dalam Air
}

\author{
Yeanchon H. Dulanlebit ${ }^{{ }^{*}}$, Sunarti ${ }^{1}$, Yustinus T. Male ${ }^{2}$ \\ 1 Program Studi Kimia, Universitas Pattimura, Ambon \\ 2 Jurusan Kimia, Universitas Pattimura, Ambon \\ “yansendulanlebit@gmail.com
}

\begin{abstract}
ABSTRAK
Biji kelor (Moringa oleifera Lamk) mengandung senyawa aktif rhamnoksiloksi benzil isotiosianat yang efektif dan digunakan untuk mengadsorpsi logam terlarut dalam air. Penelitian ini untuk menganalisis efektivitas biji kelor pada pengolahan air sumur dan waktu optimum adsorpsi serbuk biji kelor terhadap konsentrasi besi dan magnesium yang dianalisis secara spektrofotometer serapan atom. Parameter yang dianalisis untuk efektivitas biji kelor yaitu padatan terlarut (TDS), $\mathrm{pH}$ dan kesadahan. Hasil didapatkan bahwa air sumur memiliki TDS $346,874 \mathrm{mg} / \mathrm{L}$, pH 6,85 dan kesadahan $422 \mathrm{mg} / \mathrm{L}$. Efektivitas biji kelor dengan variasi pembubuhan 50, 100,150 dan 200 mg masing-masing diperoleh TDS 4,132, 3,578, 4,968, dan 4,908 mg/L, pH 7,86, 7,91, 7,92, dan 7,94 serta kesadahan 284, 278, 272, dan 266 mg/L. Biji kelor efektif dan mampu menurunkan TDS dan kesadahan air. Untuk penentuan waktu optimum adsorpsi serbuk biji kelor dilakukan pada konsentrasi $\mathrm{Fe}_{(\text {awal) }}$ dan $\mathrm{Mg}_{(\text {(awal) }}$ dalam air masing-masing 9,6677 dan 7,8156 mg/L dengan variasi waktu kontak 30, 60, 90, dan 120 menit. Hasil didapatkan kapasitas adsorpsi Fe masing-masing 90,482, 90,472, 91,882, dan 92,220 mg/Kg dimana Fe teradsorpsi optimum pada waktu kontak 120 menit dengan efisiensi adsorpsi 95,389\% sedangkan kapasitas adsorpsi Mg masing-masing 15,703, 14,733, 15,108, dan 15,520 mg/Kg dimana Mg teradsorpsi optimum pada waktu kontak 30 menit dengan efisiensi adsorpsi 20,09\%.
\end{abstract}

Kata kunci: adsorpsi, biji kelor, kualitas air, rhamnoksiloksi benzil isotiosianat

\section{PENDAHULUAN}

Air merupakan kebutuhan esensial bagi kelangsungan hidup. Teknik untuk memperoleh air bersih dan layak dikonsumsi telah banyak dikembangkan termasuk dengan memanfaatkan biji kelor (Moringa oleifera Lamk) sebagai koagulan dan adsorben. Biji kelor dinilai efektif menurunkan kekeruhan pada pengolahan air tanah dan air tercemar limbah. Biji kelor mampu mempengaruhi perubahan $\mathrm{pH}$, kekeruhan, dan padatan terlarut. Pada air limbah didapatkan biji kelor dapat menurunkan turbiditas limbah cair sebesar $98,6 \%$ dan konduktivitas $11 \%$. Pada air tanah, biji kelor mampu menurunkan turbiditas sebesar 98\% dan konduktivitas 53\% (Manurung T., dkk. 2012). Efektivitas koagulan polialuminium klorida, biji kelor dan tawas menunjukkan biji kelor mampu menurunkan turbiditas $95,39 \%$ dan warna $75,07 \%$ (Syahru R., dkk., 2013).

Biji kelor merupakan polimer organik yang mengandung protein, adanya gugus amino $\left(-\mathrm{NH}_{2}\right)$ dan karboksilat $(-\mathrm{COOH})$ menyebabkan biji kelor mempunyai reaktifitas tinggi dan bersifat polielektrolit. Sebagai polielektrolit, biji kelor dapat digunakan untuk mengadsorpsi logam terlarut dalam air. Protein pada biji kelor mengandung asam amino glutamat, metionin, dan arginin. Asam glutamat bermuatan negatif pada karboksilnya dan mengalami ionisasi jika dilarutkan dalam air sehingga kation logam terlarut terikat pada gugus hidroksil. 


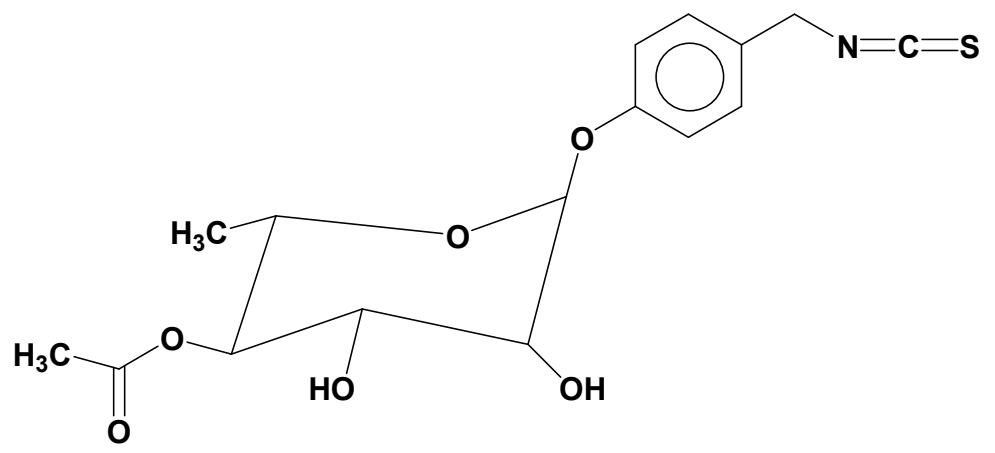

Gambar 1. Struktur rhamnoksiloksi benzil isotiosianat

Kandungan senyawa bioaktif rhamnoksiloksi benzil isotiosianat dalam biji kelor ini mampu mengadsorpsi mineral yang terkandung dalam air dan limbah suspensi sehingga sangat potensial digunakan sebagai koagulan alami (Sutanto T.D., dkk., 2007), dimana jumlah adsorben cenderung meningkatkan daya serap terhadap adsorbat (Anjani R.K., dan Koestiari T., 2014). Koagulan mengandung muatan berlawanan dengan muatan koloid akan mengadsorpsi koloid pada permukaannya dan akan menurunkan gaya tolak menolak untuk berkoagulasi (Aminzadeh B., dkk., 2007). Biji kelor mudah dimanfaatkan sebagai biokoagulan dan adsorben pada pengolahan air, terutama pengolahan air minum karena sifatnya yang tidak beracun dan mudah terurai secara alami. Kelebihan biji kelor dibanding koagulan kimia yaitu mudah dibudidayakan, lebih efektif dan mudah preparasinya. Selain mudah diperoleh, biji kelor juga mampu mengendapkan ion logam terlarut termasuk kation penyebab kesadahan air (Irianty R.S., 2010; Khairullah dan Putra A., 2008).

\section{METODE PENELITIAN}

Peralatan yang digunakan: spektrofotometer serapan atom AA-6300, spektrofotometer IR Shimadzu, pH meter, oven, hotplate, neraca analitik, buret, desikator, evaporator, pengayak 100 mesh, shaker 3005 GFL dan peralatan gelas. Bahan-bahan: sampel air, serbuk biji kelor, EDTA 0,01 $\mathrm{M}$, buffer $\mathrm{pH} 10$, EBT, metanol, kertas saring, akuades, besi murni, $\mathrm{HNO}_{3}$ pekat, $\mathrm{MgSO}_{4} .7 \mathrm{H}_{2} \mathrm{O}$, dan $\mathrm{H}_{2} \mathrm{SO}_{4}$ pekat.

\section{Prosedur Kerja}

1. Preparasi dan ekstraksi serbuk biji kelor

Biji kelor dikeringkan pada $105^{\circ} \mathrm{C}$ hingga berat konstan, dihaluskan dan diayak hingga menjadi serbuk. Ekstrak biji kelor dilakukan secara maserasi menggunakan metanol dan dilanjutkan dengan evaporasi.

2. Penentuan padatan terlarut (TDS), $\mathrm{pH}$, dan kesadahan

- Penentuan padatan terlarut : $50 \mathrm{~mL}$ sampel air dimasukan dalam erlenmeyer dan diuapkan dalam oven pada $109^{\circ} \mathrm{C}$ selama \pm 17 jam. Sampel didinginkan dan ditimbang.

$$
\operatorname{TDS}(\mathrm{mg} / \mathrm{L})=\frac{\text { berat residu } \times 1000}{\mathrm{~mL} \text { sampel }}
$$

- Penentuan $\mathrm{pH}$ : pH meter dicelupkan dalam buffer $\mathrm{pH} 10$ untuk standarisasi. Elektroda dibilas dan dikeringkan. Elektroda dimasukkan kedalam sampel, nilai pH dicatat. 
- Penentuan kesadahan total : $50 \mathrm{~mL}$ sampel air dimasukan dalam erlenmeyer, ditambahkan 1 $\mathrm{mL}$ buffer $\mathrm{pH}$ 10. Tambahkan 2 tetes indikator EBT sebelum dititrasi, dititrasi dengan EDTA $0,01 \mathrm{M}$ sampai terbentuk warna biru.

$$
\text { Kesadahan }(\mathrm{mg} / \mathrm{L})=\frac{\text { mL EDTA } \times \text { M EDTA } \times \text { BM CaCO3 x } 1000}{\text { mL sampel }}
$$

3. Efektivitas biji kelor

$50 \mathrm{~mL}$ sampel air dimasukkan kedalam masing-masing 4 gelas kimia $100 \mathrm{~mL}$. Tambahkan 50 , 100, 150 dan 200 mg serbuk biji kelor kedalam masing-masing gelas kimia. Larutan dicampur hingga homogen, didiamkan selama 60 menit dan disaring. Selanjutnya dilakukan pengukuran TDS, $\mathrm{pH}$, dan kesadahan menggunakan prosedur yang sama.

4. Penyiapan dan analisis larutan besi dan magnesium

- Pembuatan larutan standar Fe 500 ppm

$0,250 \mathrm{~g}$ serbuk besi dilarutkan dengan $\mathrm{HNO}_{3} 10 \mathrm{~mL}$ dan tambahkan aquades dalam labu takar $500 \mathrm{~mL}$ hingga tanda batas. Selanjutnya dibuat larutan standar Fe 10 ppm.

- Pembuatan larutan standar Mg 1000 ppm

$5,069 \mathrm{~g} \mathrm{MgSO} 4.7 \mathrm{H}_{2} \mathrm{O}$ dilarutkan dengan aquades dan ditambahkan 10 tetes $\mathrm{H}_{2} \mathrm{SO}_{4}$. Dimasukkan dalam labu takar $500 \mathrm{~mL}$ dan diencerkan dengan aquades hingga tanda batas. Selanjutnya dibuat larutan standar Mg 10 ppm.

- Pembuatan larutan standar Fe dan Mg

Larutan standar Fe 0,2, 0,4, 0,6 dan 0,8 ppm dibuat dengan memipet Fe 10 ppm sebanyak 2, 4 , 6, dan $8 \mathrm{~mL}$, kemudian dimasukkan dalam labu takar $100 \mathrm{~mL}$ dan diencerkan dengan aquades sampai tanda batas. Larutan Fe diukur serapannya dan dibuat kurva absorbansi vs konsentrasinya. Prosedur yang sama dilakukan untuk larutan Mg.

5. Adsorpsi Fe dan Mg

Sampel Fe disaring dan dimasukan kedalam 5 erlenmeyer masing-masing sebanyak $50 \mathrm{~mL}$. Selanjutnya dimasukkan $5 \mathrm{~g}$ serbuk biji kelor kedalam 4 sampel air. Sampel air yang telah ditambahkan adsorben diaduk dengan kecepatan 250 rpm pada variasi waktu kontak 30, 60, 90, dan 120 menit. Sampel air dipisahkan dari endapan dan dianalisis. Prosedur yang sama dilakukan untuk adsorpsi Mg.

6. Berdasarkan pengukuran larutan standar $\mathrm{Fe}$ dan $\mathrm{Mg}$, maka dibuat grafik absorbansi vs konsentrasi, ini bertujuan untuk mendapatkan persamaan regresi. Untuk kapasitas adsorpsi biji kelor terhadap Fe dan Mg digunakan persamaan:

$$
\text { Kapasitas adsorpsi }(\mathrm{mg} / \mathrm{Kg})=\frac{\mathrm{V}(\mathrm{Co}-\mathrm{Ca})}{\mathrm{m}}
$$

dimana : $\mathrm{V}=$ volume sampel $(\mathrm{L})$, Co $=$ Konsentrasi awal $(\mathrm{mg} / \mathrm{L}), \mathrm{Ca}=$ konsentrasi hasil pengukuran kurva standar (mg/L), dan $\mathrm{m}=$ massa adsorben $(\mathrm{Kg})$ (Baidho Z., dkk., 2013).

Untuk mengukur efisiensi adsorpsi digunakan persamaan :

$$
\text { Efisiensi adsorpsi }=\frac{a-b}{a} \times 100 \%
$$

dimana: $a=$ konsentrasi sebelum dikontakkan dengan adsorben, $b=$ konsentrasi setelah dikontakkan (Asbahani, 2013). 


\section{HASIL PENELITIAN}

Biji kelor (Moringa oleifera $L$ ) merupakan adsorben dan biokoagulan dalam proses pengolahan air, dimana ekstrak yang diperoleh dianalisis untuk mengetahui adanya gugus fungsi yang terkandung dalam biji kelor.

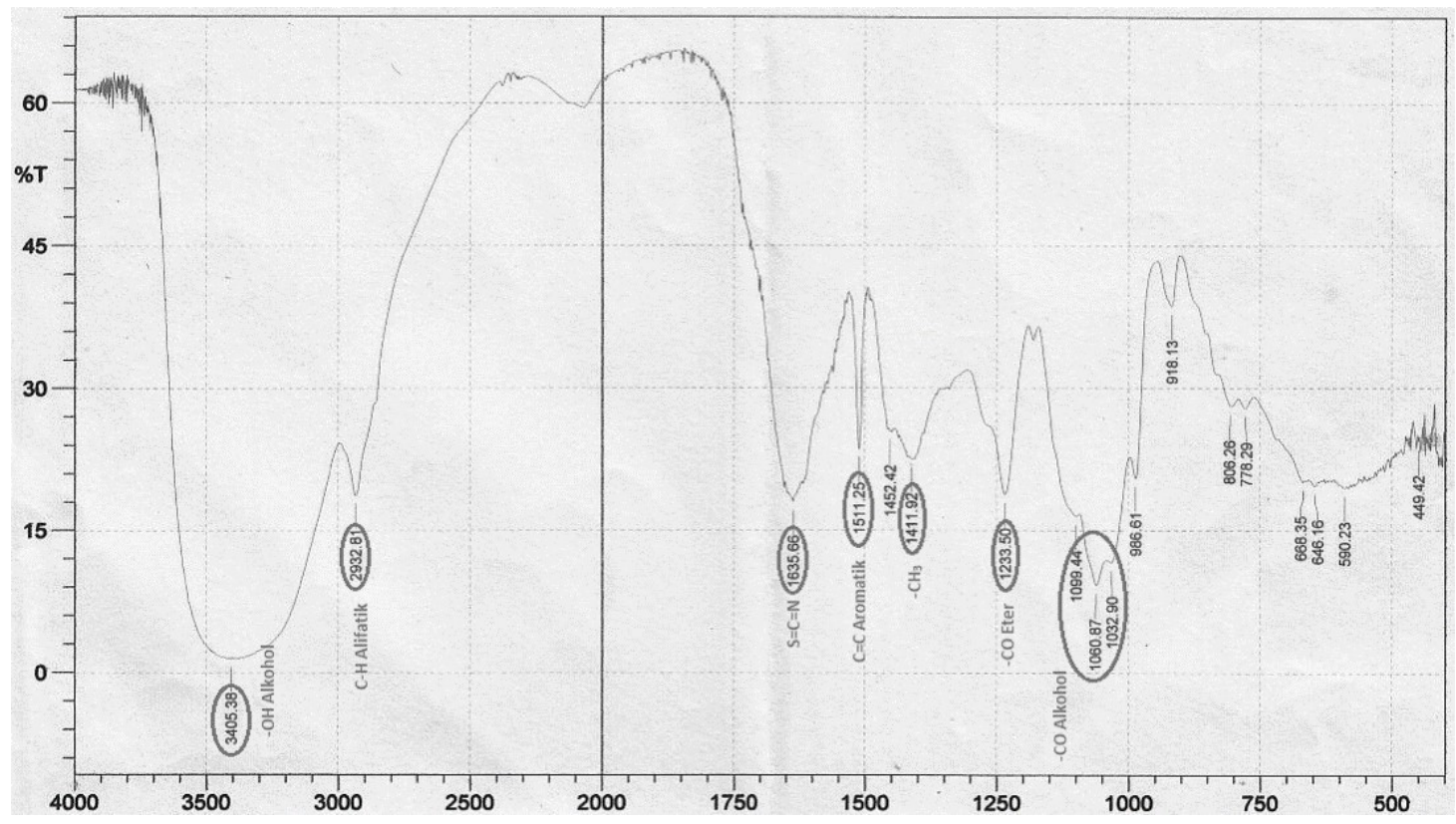

Gambar 2. Spektra infrared ekstrak biji kelor

Data spektra terlihat pita lebar dan kuat pada $3405,38 \mathrm{~cm}^{-1}$ yang merupakan gugus $\mathrm{O}-\mathrm{H}$ diperkuat dengan serapan $\mathrm{C}-\mathrm{O}$ eter pada $1233,50 \mathrm{~cm}^{-1}$; SCN pada $1635,66 \mathrm{~cm}^{-1}$; serapan $\mathrm{C}=\mathrm{C}$ aromatik pada $1511,25 \mathrm{~cm}^{-1}$ diperkuat serapan pada $806,26 \mathrm{~cm}^{-1}$ yang menjadi ciri khas adanya senyawa aromatik; $\mathrm{CH}$ terkonjugasi dari aromatik ditunjukkan pada $2931,81 \mathrm{~cm}^{-1}$; serapan pada $1411,92 \mathrm{~cm}^{-1}$ menunjukkan adanya $\mathrm{CH}$ alifatik. Hasil analisis senyawa terekstrak merupakan 4a-4ramnosiloxi benzil isotiosianat. Dosis biji kelor yang ditambahkan sangat mempengaruhi proses koagulasi, dosis yang tepat diperlukan agar koagulasi berjalan efektif dan terbentuk flok.

1. Padatan terlarut (TDS)

TDS merupakan ukuran zat organik dan anorganik terlarut dalam larutan.

Tabel 1. Hasil Padatan Terlarut (TDS)

\begin{tabular}{|c|c|}
\hline Dosis pembubuhan $(\mathrm{mg})$ & Nilai TDS $(\mathrm{mg} / \mathrm{L})$ \\
\hline 0 & 346,874 \\
\hline 50 & 4,132 \\
\hline 100 & 3,578 \\
\hline 150 & 4,968 \\
\hline 200 & 4,908 \\
\hline
\end{tabular}


Persentase penurunan nilai TDS pada serbuk biji kelor untuk dosis 50 mg mampu menurunkan TDS air sumur 98,81\%, dan untuk dosis 100, 150 dan $200 \mathrm{mg}$ sebesar 98,97\%, 98,57\% dan $98,59 \%$. Penurunan TDS optimum pada penambahan $100 \mathrm{mg}$ serbuk biji kelor, sedangkan pada $150 \mathrm{mg}$ dan $200 \mathrm{mg}$ terjadi peningkatan TDS. Ini disebabkan terlarutnya sebagian kandungan senyawa organik dalam biji kelor. Nilai TDS juga berpengaruh terhadap kesadahan air, jika TDS meningkat maka kesadahan air akan meningkat.

2. Derajat Keasaman (pH)

$\mathrm{pH}$ air menyatakan intensitas asam atau basa suatu larutan.

Tabel 2. Hasil Pengukuran $\mathrm{pH}$

\begin{tabular}{|l|c|c|c|c|c|}
\hline \multirow{2}{*}{$\begin{array}{l}\text { Nilai } \mathrm{pH} \\
\text { rata-rata }\end{array}$} & \multicolumn{5}{|c|}{ Dosis pembubuhan } \\
\cline { 2 - 6 } & $0 \mathrm{mg}$ & $50 \mathrm{mg}$ & $100 \mathrm{mg}$ & $150 \mathrm{mg}$ & $200 \mathrm{mg}$ \\
\cline { 2 - 6 } & 6,85 & 7,86 & 7,91 & 7,92 & 7,95 \\
\hline
\end{tabular}

Persentase kenaikan nilai $\mathrm{pH}$ air akibat proses pengolahan air dengan serbuk biji kelor untuk variasi pembubuhan 50,100, 150 dan $200 \mathrm{mg}$ berturut-turut 14,74\%,15,47\%,15,62\% dan $16,06 \%$. Penambahan variasi serbuk biji kelor mengakibatkan $\mathrm{pH}$ cenderung meningkat. Peningkatan disebabkan karena protein kationik biji kelor yaitu rhamnoksiloksi benzil isotiosianat yang tidak memerlukan zat pereduksi dalam proses koagulasi yang akan menghasilkan suatu asam. Larutan menjadi bersifat basa disebabkan kekuatan serbuk biji kelor sebagai koagulan terletak pada keberadaan protein kationik yang larut dalam air sehingga terjadi penerimaan proton dari air oleh asam amino yang bersifat basa yang terdapat dalam protein biji kelor yang menghasilkan pelepasan gugus hidroksil yang membuat larutan menjadi basa (Amagloh F.K., and Benang A., 2009). pH juga mempengaruhi kesadahan dimana jika kesadahan tinggi maka air akan bersifat basa, pada $\mathrm{pH}$ tinggi penyerapan ion logam tidak optimum dimana ion logam membentuk endapan hidroksida sehingga proses adsorpsi sulit terjadi (Marlinawati, dkk., 2015).

3. Kesadahan

Kesadahan adalah sifat air yang disebabkan oleh mineral. Air yang bersifat basa merupakan air sadah.

Tabel 3. Hasil Analisis Kesadahan

\begin{tabular}{|c|c|}
\hline $\begin{array}{c}\text { Dosis Pembubuhan } \\
(\mathrm{mg})\end{array}$ & $\begin{array}{c}\text { Total Kesadahan } \\
(\mathrm{mg} / \mathrm{L})\end{array}$ \\
\hline 0 & 422 \\
\hline 50 & 284 \\
\hline 100 & 278 \\
\hline 150 & 272 \\
\hline 200 & 266 \\
\hline
\end{tabular}

Persentase penurunan kesadahan air setelah dikontakkan dengan serbuk biji kelor 50, 100, 150, dan 200 mg berturut-turut 32,70\%, 34,12\%, 35,55\%, dan 36,97\%. Penurunan kesadahan tertinggi pada dosis $200 \mathrm{mg}$ dikarenakan zat aktif rhamnoksiloksi benzil isotiosianat yang merupakan protein kationik mampu mengadsorpsi logam terlarut dalam air.

4. Adsorpsi Besi 
Dari nilai konsentrasi dan serapan Fe dan Mg didapatkan persamaan regresi $y=0,0334 x+0,0008$ dan $y=0,7642 x+0,0663$ dengan nilai $R^{2}$ mendekati satu. Waktu kontak berkaitan dengan kemampuan adsorben biji kelor dalam menurunkan konsentrasi Fe dan Mg dalam air (Tabel 4 dan Tabel 5).
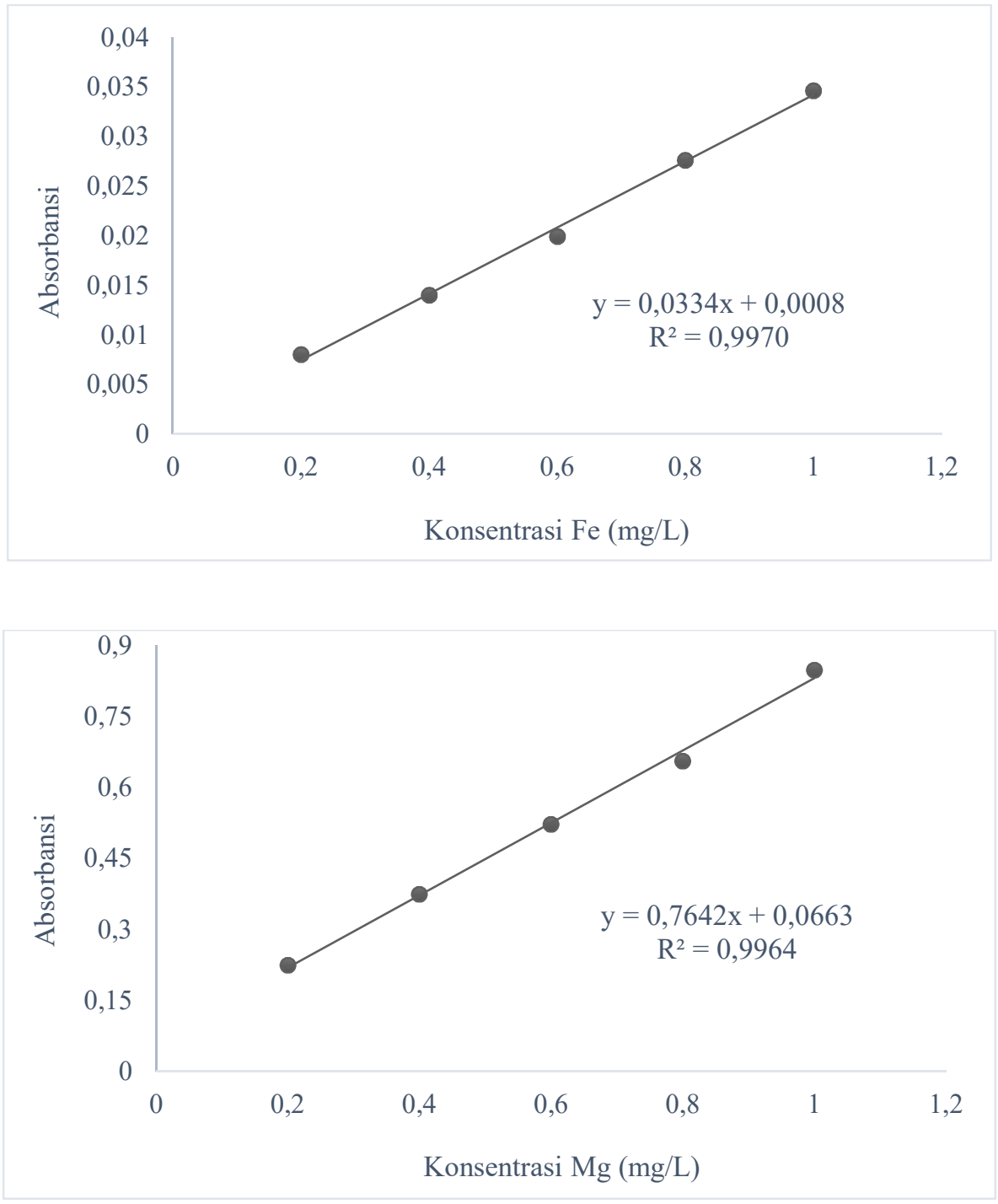
Tabel 4. Waktu Kontak Optimum Adsorpsi Terhadap Fe

\begin{tabular}{|c|c|c|c|}
\hline $\begin{array}{c}\text { Waktu Kontak } \\
\text { (menit) }\end{array}$ & Abs & $\begin{array}{c}{[\mathrm{Fe}] \text { sisa adsorpsi }} \\
(\mathrm{mg} / \mathrm{L})\end{array}$ & $\begin{array}{c}\text { Kapasitas Adsorpsi Biji Kelor } \\
(\mathrm{mg} / \mathrm{Kg})\end{array}$ \\
\hline $\begin{array}{c}\text { (tanpa adsorben) } \\
\text { (tan }\end{array}$ & 0,0145 & 9,6677 & 0 \\
\hline 60 & 0,0219 & 0,6195 & 90,482 \\
\hline 90 & 0,0220 & 0,6205 & 90,472 \\
\hline 120 & 0,0175 & 0,4795 & 91,882 \\
\hline & 0,0164 & 0,4457 & 92,220 \\
\hline
\end{tabular}

Tabel 5. Waktu Kontak Optimum Adsorpsi Terhadap Mg

\begin{tabular}{|c|c|c|c|}
\hline $\begin{array}{c}\text { Waktu Kontak } \\
\text { (menit) }\end{array}$ & Abs & $\begin{array}{c}\text { [Mg] sisa adsorpsi } \\
\text { (mg/L) }\end{array}$ & $\begin{array}{c}\text { Kapasitas Adsorpsi Biji Kelor } \\
\text { (mg/Kg) }\end{array}$ \\
\hline $\begin{array}{c}0 \\
\text { (tanpa adsorben) }\end{array}$ & 0,7305 & 7,8156 & 0 \\
\hline 30 & 0,5928 & 6,2453 & 15,703 \\
\hline 60 & 0,6012 & 6,3423 & 14,733 \\
\hline 90 & 0,5983 & 6,3048 & 15,108 \\
\hline 120 & 0,5944 & 6,2636 & 15,520 \\
\hline
\end{tabular}

Dari hasil didapatkan kapasitas adsorpsi Fe oleh biji kelor semakin meningkat dengan bertambahnya waktu kontak. Semakin lama waktu kontak maka semakin banyak serbuk biji kelor akan bersinggungan dengan mineral $\mathrm{Fe}$ dalam air, dimana waktu kontak yang lama mengakibatkan adsorbat dapat terserap kedalam pori-pori adsorben. Fe teradsorpsi optimum pada waktu 120 menit, dengan efisiensi adsorpsi 95,389\%. Kapasitas adsorpsi Mg oleh biji kelor optimum pada waktu kontak 30 menit, dimana penyerapan $\mathrm{Mg}$ oleh biji kelor telah maksimal, dengan efisiensi adsorpsi 20,09\%.

5. Reaksi Penyerapan Fe dan Mg 

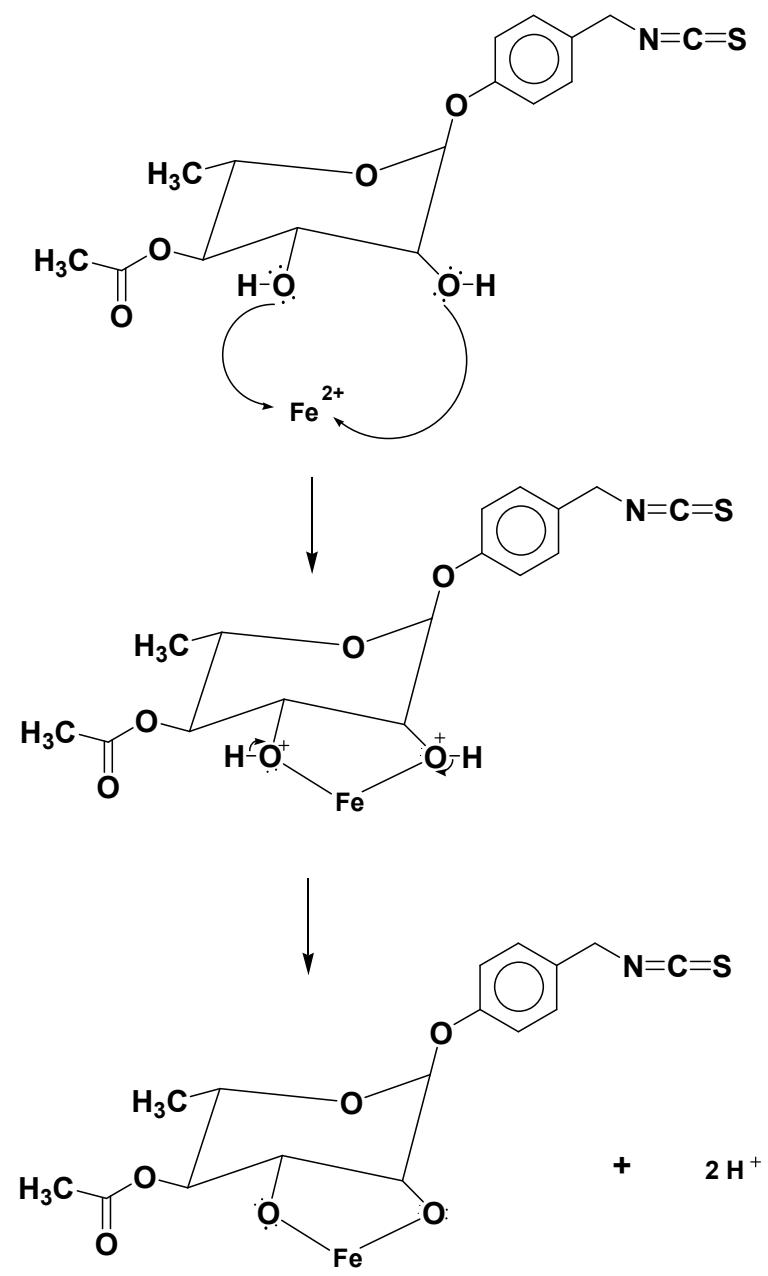

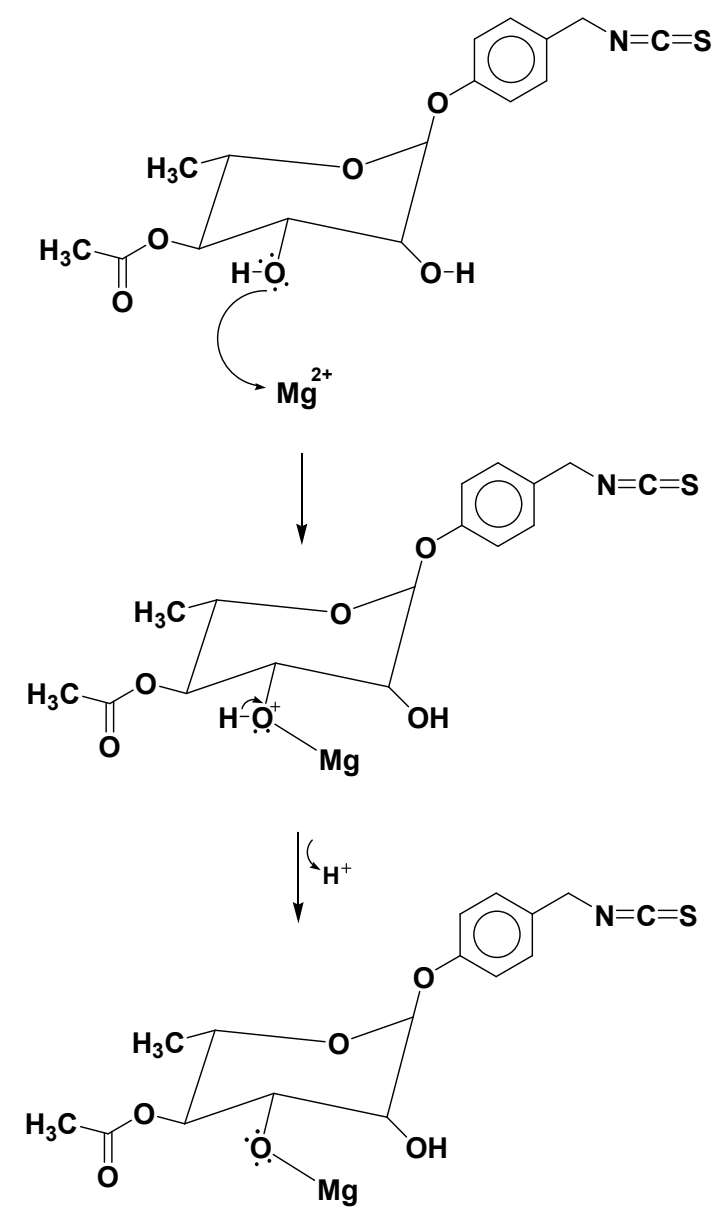

\section{KESIMPULAN}

Biji kelor (Moringa oleifera Lamk) mengandung rhamnoksiloksi benzil isotiosianat yang efektif untuk mengadsorpsi logam terlarut. Hasil didapatkan air sumur memiliki TDS 346,874 mg/L, pH 6,85 dan kesadahan $422 \mathrm{mg} / \mathrm{L}$. Variasi pembubuhan 50, 100, 150 dan $200 \mathrm{mg}$ diperoleh TDS 4,132, 3,578, 4,968, dan 4,908 mg/L, pH 7,86, 7,91, 7,92, dan 7,94 serta kesadahan 284, 278, 272, dan $266 \mathrm{mg} / \mathrm{L}$. Untuk waktu optimum adsorpsi serbuk biji kelor pada konsentrasi $\mathrm{Fe}_{(\text {awal) }}$ dan $\mathrm{Mg}_{\text {(awal) }}$ dalam air masing-masing 9,6677 dan 7,8156 mg/L dengan variasi waktu kontak 30, 60, 90, dan 120 menit didapatkan kapasitas adsorpsi Fe 90,482, 90,472, 91,882, dan 92,220 mg/Kg dimana Fe teradsorpsi optimum pada 120 menit dengan efisiensi adsorpsi 95,389\%. Kapasitas adsorpsi Mg 15,703, 14,733, 15,108, dan 15,520 mg/Kg dimana Mg teradsorpsi optimum pada 30 menit dengan efisiensi adsorpsi $20,09 \%$. 


\section{DAFTAR PUSTAKA}

Anjani R.K., dan Koestiari T., "Penentuan Massa dan Waktu Kontak Optimum Adsorpsi Granular sebagai Logam Berat Pb (II) dengan Pesaing lon Na+", Journal of Chemistry, Vol. 3, No. 3 (2014).

Amagloh F.K., and Benang A., "Effectiveness of Moringa Oleifera Seed As Coagulant For Water Purification", African Journal of Agricultural Research, Vol. 4, No. 1 (2009).

Aminzadeh B., dkk., "Pretreatment of Municipal Wastewater By Enhanced Chemical Coagulation", International Journal Environment Research, Vol. 1, No. 2 (2007).

Asbahani., "Pemanfaatan Limbah Ampas Tebu Sebagai Karbon Aktif Untuk Menurunkan Kadar Besi Pada Air Sumur", Jurnal Teknik Sipil, Vol. 13, No. 1 (2013).

Baidho Z., dkk., "Adsorpsi Logam Berat Pb Dalam Larutan Menggunakan Senyawa Xanthate Jerami Padi", Prosiding SNST, Semarang (2013).

Irianty R.S., "Pengaruh Massa Biji Kelor (Moringa oleifera Lamk) dan Waktu Pengendapan Pada Pengolahan Air Gambut", Jurnal Sains dan Teknologi Fakultas Teknik Universitas Riau (2010).

Khairullah dan Putra A., "Optimalisasi Aerasi Difusi Sebagai Penurunan Sadah Sintetik Air", Jurnal Reaksi (Jounal of Science \& Technology), Vol. 6, No. 11 (2008).

Manurung T., dkk., "Efektifitas Biji Kelor (Moringa oleifera) Pada Pengolahan Air Sumur Tercemar Limbah Domestik", Jurnal IImiah Fakultas Teknik Limit's, Vol. 8, No. 1 (2012).

Marlinawati, dkk., "Pemanfaatan Arang Aktif dari Kulit Durian (Durio zibethinus L) Sebagai Adsorben Ion Logam Kadmium (II)", Jurnal Kimia, Vol. 13, No. 1 (2015).

Sutanto T.D., dkk., "Buah Kelor (Moringa oleifera Lamk) Tanaman yang Dapat Digunakan Untuk Mengurangi Kadar Ion Logam Dalam Air", Jurnal Gradien, Vol. 3, No.1 (2007).

Syahru R., dkk., "Perbandingan Efektivitas Tepung Biji Kelor (Moringa oleifera Lamk), Poly Aluminium Chloride (PAC), dan Tawas sebagai Koagulan untuk Air Jernih", Jurnal Keteknikan Pertanian Tropis dan Biosistem, Vol. 1, No. 3 (2013). 